BARTŁOMiEJ PATKOWsKi

Uniwersytet Pedagogiczny, Kraków, Polska

\title{
Rozwój Systemów Informacji Prawnej oraz ich rola w ksztaltowaniu gospodarki opartej na wiedzy (na przykładzie Polski)
}

\author{
The Development of Computer-Assisted Legal Research \\ Systems and Their Role in Shaping a Knowledge-Based \\ Economy (on the Example of Poland)
}

\begin{abstract}
Streszczenie: Dla wszystkich uczestników rynku odpowiednio usystematyzowana informacja prawna jest kluczowa z punktu widzenia podejmowania decyzji, co przekłada się na funkcjonowanie przedsiębiorstw, instytucji państwowych, a także poszczególnych osób fizycznych. W Polsce po okresie transformacji pojawiły się na rynku narzędzia informatyczne, które dały początek obecnie istniejącym i bardzo rozbudowanym systemom informatycznym określanym jako Systemy Informacji Prawnej (SIP). Celem niniejszego opracowania jest przedstawienie czynników determinujących powstanie i rozwój Systemów Informacji Prawnej w Polsce, a przede wszystkim zobrazowanie roli jaką odegrały one w upowszechnianiu informacji prawnej i ekonomicznej. SIP wykształciły się w Polsce przede wszystkim wskutek niestabilności i nadmiernej szczegółowości polskiego ustawodawstwa. W początkowym okresie rozwoju systemy te stały się ważnym narzędziem pracy głównie wśród prawników. W miarę upływu czasu zaczęły się rozprzestrzeniać poza tradycyjny rynek, docierając do przedsiębiorców i instytucji publicznych. Dały one także impuls do tworzenia wielu innych narzędzi informatycznych przekazujących informację prawną i ekonomiczną do szerokiego kręgu odbiorców. Systemy Informacji Prawnej odgrywają znaczącą rolę w kształtowaniu gospodarki opartej na wiedzy. Rola ta polega na zbliżeniu wiedzy i informacji do procesów decyzyjnych w sektorze prywatnym i publicznym.
\end{abstract}

Abstract: For all market participants, appropriately structured legal information is crucial for the pro-
cess of decision-making, which is reflected in the operation of businesses, government agencies, and
individuals. In Poland, after the 1989 transition, IT tools appeared on the market giving rise to currently
used, highly developed systems known as Computer-Assisted Legal Research (CALR). The purpose of
this paper is to present the factors that underlay the origin and development of Legal Research Systems
in Poland and, in particular, to outline their role they played in dissemination of legal and business
information. CARL developed in Poland primarily as a result of instability and excessive minuteness
of Polish law. Initially such systems gained popularity primarily among lawyers as an important work
tool. As time passed, CARL has spread beyond the traditional market, reaching businesses and public 
institutions. Additionally, it provided strong impetus to create other IT tools transferring information of legal and economic to general public. Legal Research Systems play a significant role in shaping a knowledge-based economy. This role is based on convergence of knowledge and information necessary for decision-making in the private and public sectors.

Słowa kluczowe: System Informacji Prawnej, gospodarka oparta na wiedzy, sprzedaż bezpośrednia

Key words: Computer-Assisted Legal Research System, knowledge-based economy, direct sale

\section{WPROWADZENIE}

Ostatnie dziesięciolecia rozwoju gospodarki światowej charakteryzują się postępującą globalizacją, czego efektem jest wzrost znaczenia informacji jako głównego czynnika rozwoju. Z drugiej strony, poprzez ułatwiony dostęp do informacji niesłychanie ważna staje się jej odpowiednia selekcja i systematyzacja. Dla wszystkich uczestników rynku, a w szczególności dla podmiotów gospodarczych, odpowiednio usystematyzowana informacja prawna jest kluczowa z punktu widzenia podejmowania decyzji, co przekłada się na funkcjonowanie przedsiębiorstw, instytucji państwowych, a także poszczególnych osób fizycznych. W Polsce po okresie transformacji pojawiły się na rynku narzędzia informatyczne, które dały początek obecnie istniejącym i bardzo rozbudowanym systemom informatycznym określanym jako Systemy Informacji Prawnej (SIP). Celem niniejszego opracowania jest przedstawienie czynników determinujących powstanie i rozwój SIP, a przede wszystkim zobrazowanie roli jaką odegrały one w upowszechnianiu informacji prawnej i ekonomicznej w Polsce. Wiele uwagi poświęcono także metodom dystrybucji SIP, zarówno w aspekcie czynników rozwoju tychże systemów, jak i w aspekcie kształtowania świadomości prawnej, ekonomicznej czy informatycznej społeczeństwa. Artykuł oparty jest przede wszystkim na wieloletniej obserwacji uczestniczącej autora.

\section{Rozwinięcie pojęcia System Informacji Prawnej}

Pojęcie „System Informacji Prawnej” definiowane jest w literaturze naukowej w ramach dziedziny wiedzy określanej jako informatyka prawnicza. Według G. Wierczyńskiego i W.R. Wiewiórowskiego (2012: 75-76) przez SIP należy rozumieć prawnicze programy horyzontalne, czyli takie, których bazy mają z założenia obejmować jak najszerszy zakres tematyki prawnej, dążąc do uwzględnienia całości informacji prawnej i prawniczej w Polsce. SIP należy także rozumieć jako zbiór baz danych, co przedstawia ryc. 1. Inny cel niż SIP, realizowany jest w programach wertykalnych. Autorzy tej grupy baz nie przedstawiają całości prawa, lecz wybierają zeń pewien wycinek, przedstawiając program komputerowy, którego zamierzeniem jest ujęcie tematyki prawnej w sposób idealnie dopasowany do wymagań danej branży lub danego odbiorcy. 


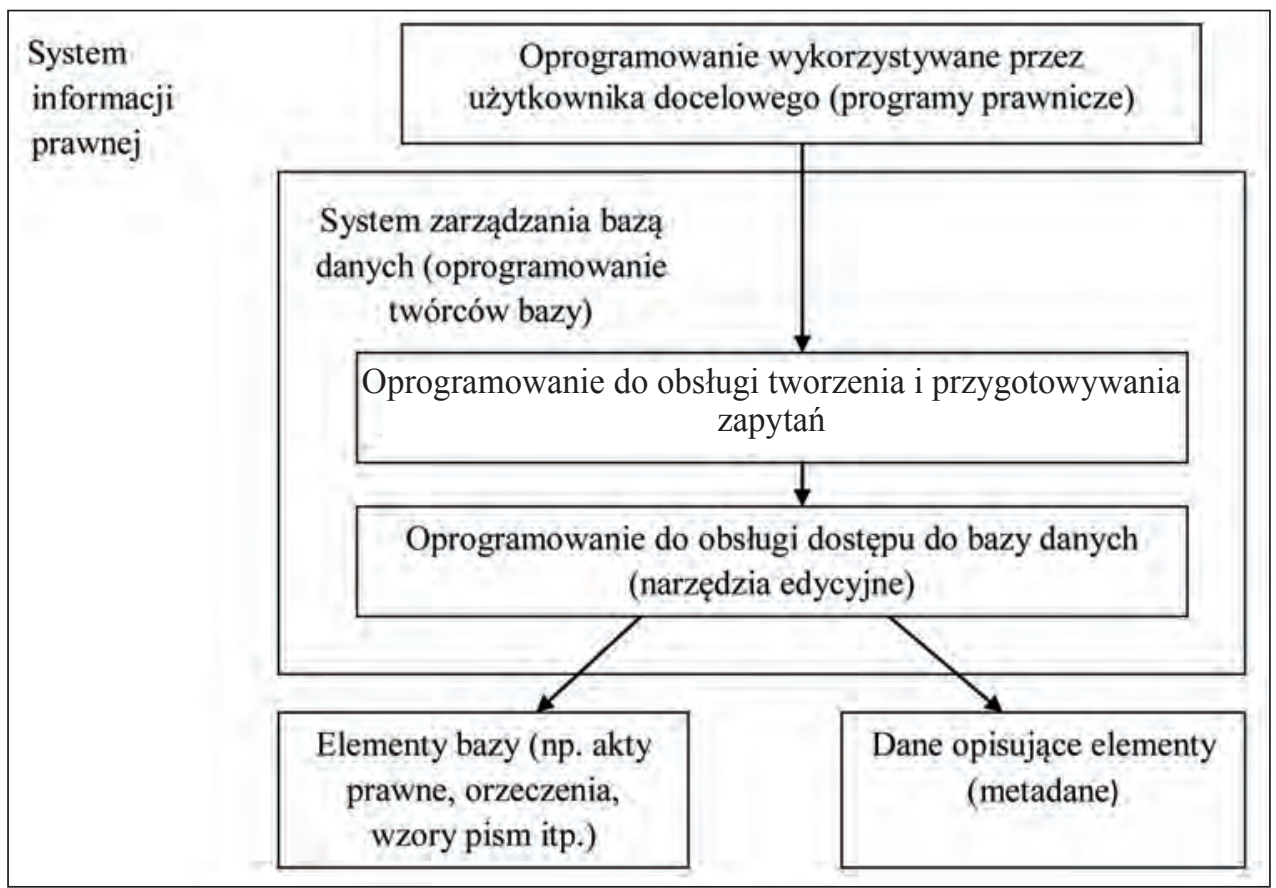

Ryc. 1. Różne rozumienie pojęcia „,bazy danych”

Źródło: Wierczyński, Wiewiórowski 2012

Zdaniem J. Janowskiego (2011: 100) należy odróżnić termin „system informatyczny prawa” od terminu „system informacji prawnej”. Ten pierwszy uwzględnia wszelkie programy komputerowe, dedykowane lub tylko adaptowane dla potrzeb tworzenia, stosowania, przestrzegania, wykonywania, egzekwowania, badania i upowszechniania prawa (realizacji prawnych procesów i operacji informacyjnych). Natomiast w powszechnym użyciu określenie „system informacji prawnej” dotyczy zinformatyzowanych systemów w postaci prawnych i prawniczych baz danych.

Pojęcie SIP jest często nadużywane przez producentów różnego typu programów i serwisów internetowych. Służy to z reguły podniesieniu rangi danemu serwisowi, ale powoduje, że termin ten staje się niejasny dla potencjalnych klientów (użytkowników). Dlatego też dla potrzeb niniejszego opracowania podjęto próbę zdefiniowania pojęcia SIP, uwzględniając terminologię stosowaną przez informatykę prawniczą, jak i przykłady rynkowe. Poprzez System Informacji Prawnej rozumiane są systemy informatyczne, które dostarczają użytkownikom aktualne, usystematyzowane i kompleksowe informacje z zakresu prawodawstwa danego państwa (i/lub innych struktur organizacyjnych, np. Unii Europejskiej) oraz wykładni prawa. Systemy te za pomocą różnych metod wyszukiwania umożliwiają szybkie dotarcie do właściwych informacji. Zazwyczaj funkcjonują one w oparciu o relacyjną bazę danych oraz program interfejsowy służący do jej obsługi. Obecnie w Polsce Systemy Informacji Prawnej obejmują najczęściej następujące składowe: 
a) akty prawne (obowiązujące, archiwalne i projektowane):

- ujednolicone (na bieżąco wprowadzane są zmiany do tekstu aktu prawnego),

- oryginały (wersja aktu prezentowana jako fotografia danego publikatora),

- metryki (kompleksowa informacja o akcie prawnym, jego tytule, rodzaju, datach wydania, publikacji, wejścia w życie, obowiązywaniu lub uchyleniu, zmianach),

b) orzecznictwo i wyjaśnienia:

- orzecznictwo sądów (publikowane i niepublikowane),

- wyjaśnienia Urzędów i Izb Skarbowych oraz interpretacje Ministra Finansów,

c) wzory pism i dokumentów:

- wzory urzędowe (w tym formularze),

- wzory pism procesowych,

- wzory umów,

d) komentarze, porady, artykuły,

e) akty prawne Unii Europejskiej,

f) orzecznictwo sądów europejskich (Europejski Trybunał Sprawiedliwości, Europejski Trybunał Praw Człowieka).

\section{RYS HISTORYCZNY}

Systemy Informacji Prawnej rozwinęły się w połowie lat sześćdziesiątych, równolegle w Stanach Zjednoczonych i w Europie Zachodniej. W Stanach Zjednoczonych funkcjonują dwie największe prawnicze bazy danych - LexisNexis i Westlaw.

W Europie Środkowo-Wschodniej prawnicze bazy danych do końca okresu komunizmu powstawały w ramach tzw. państwowej gospodarki planowej. W połowie lat siedemdziesiątych XX wieku w większości państw komunistycznych tej części Europy rozpoczęto realizację wieloletniego planu, w ramach którego miały powstać m.in. komputerowe bazy aktów prawnych. W ZSRR utworzono system dla całego kraju oraz mniejsze systemy z prawem poszczególnych republik związkowych. Podobne systemy powstały w Czechosłowacji i na Węgrzech. Na początku lat dziewięćdziesiątych XX wieku w większości państw Europy Środkowo-Wschodniej zaczęły się pojawiać komercyjne Systemy Informacji Prawnej, które natychmiast stały się bardzo popularne. W efekcie w ciągu ostatnich dwudziestu lat w tej części Europy wykształciły się systemy, które od zwykłych baz danych z informacją prawną różnią się znacznie większym zaawansowaniem funkcjonalności (Wierczyński, Wiewiórowski 2012).

W Polsce prace nad pierwszą bazą danych, zawierającą szeroki zakres informacji prawnych, rozpoczęto w latach siedemdziesiątych XX wieku. W wyniku tych prac powstał zbiór niezależnych baz danych, które nie odniosły sukcesu rynkowego. Do dzisiaj funkcjonuje część państwowego systemu informatycznego, zawierającego usystematyzowany zbiór aktów prawnych, pod nazwą ISAP (Internetowy System Aktów Prawnych). System ten jest ogólnie dostępny na stronie Sejmu RP. 
Na początku lat dziewięćdziesiątych powstał pierwszy komercyjny System Informacji Prawnej - SIP Lex. Od tego momentu można mówić o polskich SIP w rozumieniu definicji przedstawionej w pierwszej części niniejszego artykułu. Obecnie do klasycznych Systemów Informacji Prawnej zaliczyć można:

a) SIP Lex (Wolters Kluwer Polska),

b) Serwis Prawniczy LexPolonica (LexisNexis Polska),

c) SIP Legalis (Wydawnictwo C.H. Beck),

d) SIP Kwantum (Wydawnictwo Kwantum),

e) INFORLEX.PL (Infor Ekspert).

Większość powyższych systemów ma także swoje wertykalne odmiany skierowane do różnych grup potencjalnych odbiorców (np. księgowość, kadry i płace, kadra zarządzająca, studenci). Walka rynkowa podmiotów dostarczających przetworzoną informację prawną wykształciła w Polsce systemy, których zasób informacyjny, możliwości techniczne oraz ergonomia używania pozwalają uznać Polskę za jednego z liderów na rynku podobnego oprogramowania w Europie (Wiewiórowski 2008: 86).

\section{Rozwó Systemów Informacj PrawneJ}

Podstawowymi przyczynami powstania Systemów Informacji Prawnej w Polsce były: rozwój technologii informatycznych, który dokonał się po transformacji ustrojowej w 1989 roku, a przede wszystkim skokowy wzrost liczby aktów prawnych publikowanych w Dzienniku Ustaw, Monitorze Polskim i innych oficjalnych publikatorach. Bardzo dobrze obrazuje to ryc. 2 .

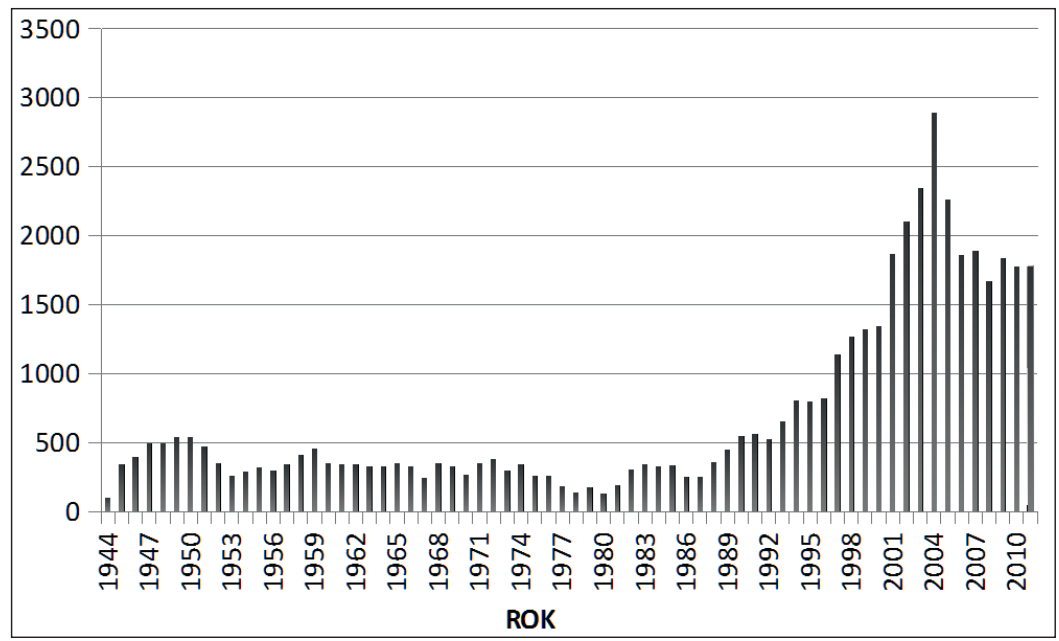

Ryc. 2. Liczba aktów prawnych opublikowanych w Dzienniku Ustaw w latach 1944-2011

Źródło: opracowanie własne na podstawie Internetowego Systemu Aktów Prawnych (ISAP) 
W latach 1944-1989 w Dzienniku Ustaw ukazywało się od 99 do 538 aktów normatywnych rocznie. Najczęściej liczba ta nieco przekraczała 300. W latach 1990-1999 wzrosła ona z 547 do ponad 1300 aktów prawnych. Jeszcze wyższa była po dwutysięcznym roku, osiągając apogeum w 2004 roku, kiedy to w Dzienniku Ustaw opublikowano prawie 2900 aktów prawnych. Według J. Kochanowskiego (2006) może to być związane z dużym natężeniem reform przeprowadzanych na przełomie lat osiemdziesiątych i dziewięćdziesiątych, z uchwaleniem Konstytucji RP w 1997 roku oraz dostosowaniem polskiego prawa do standardów Unii Europejskiej. Z. Zioło (2010) słusznie podkreśla, że na funkcjonowanie przedsiębiorstw wpływa jakość instrumentów pośredniego i bezpośredniego oddziaływania, które określa władza ustawodawcza, a wdraża rząd. Bardzo ważna jest jakość i stałość stosowanych instrumentów.

Przyczyny związane $\mathrm{z}$ transformacją ustrojową oraz $\mathrm{z}$ dostosowywaniem prawa do standardów Unii Europejskiej nie tłumaczą w pełni tak dużego wzrostu liczby aktów normatywnych. Dużą rolę odgrywa tu także wadliwy proces legislacyjny (polityzacja procesu legislacyjnego). Świadczy o tym m.in. wzrost liczby aktów prawnych w latach wyborczych i bałagan nowelizacyjny (np. praktyka nowelizowania przepisów, które nie weszły jeszcze w życie) (Goetz, Zubek 2005; Kochanowski 2006). W takich warunkach funkcjonowanie nawet profesjonalistów z zakresu prawa (adwokatów, radców prawnych, notariuszy, sędziów i prokuratorów) stawało się niezwykle trudne. Korzystanie z tradycyjnych źródeł informacji prawnej, takich jak papierowe wydania Dzienników Ustaw i innych publikatorów, pochłaniało wiele czasu i powodowało gromadzenie dużej ilości materiałów. Powstanie pierwszego Systemu Informacji Prawnej było odpowiedzią na potrzeby ze strony rynku. Rewolucyjne okazały się rozwiązania technologiczne pozwalające na czytanie aktu prawnego w postaci ujednoliconej (zaktualizowanej przez wydawcę), a także takie, jak np. powiązania pomiędzy aktami czy pomiędzy aktami i orzecznictwem. Wszystko to powodowało bardzo dużą oszczędność czasu. W kolejnych latach pojawiali się nowi producenci SIP i dzięki temu rynek stawał się coraz bardziej konkurencyjny. Systematycznie rosła też zawartość i funkcjonalność tych narzędzi. W początkowym okresie rozwoju Systemy Informacji Prawnej dystrybuowane były na dyskietkach, następnie na płytach CD i DVD. Obecnie popularną formą korzystania z SIP są dostępy on-line.

Systemy Informacji Prawnej w latach dziewięćdziesiątych stały się ważnym narzędziem pracy głównie wśród prawników. Równolegle do nich funkcjonował rynek publikacji wymiennokartkowych, które adresowane były do odbiorców korzystających z danego wycinka prawa. W późniejszym okresie publikacje wymiennokartkowe powoli przekształcały się w elektroniczne wertykalne systemy prawne. W ostatnich latach wielu wydawców (nie tylko wydawnictw fachowych) zaczęło dołączać do swoich publikacji papierowych płyty CD z przepisami prawnymi, orzecznictwem, poradami, artykułami czy wzorami umów i pism. Czasami wydania te ograniczały się wyłącznie do konkretnych aktów prawnych i wykładni z nimi związanej, a czasami obejmowały znacznie szerszy zakres informacji. Wraz z rozwojem Internetu pojawiło się także na rynku wiele dziedzinowych serwisów on-line, w których przedstawiane są aspekty prawne funkcjonowania różnych zawodów i sektorów gospodarki. Powoli zaciera się sztywny podział na systemy horyzontalne (SIP) i systemy wertykalne. 
Wynika to z tego, że część różnego typu serwisów (czy to na płytach CD czy on-line) rozwija się także horyzontalnie, dodając do swoich zbiorów np. kolejne akty prawne. Oczywiście wciąż klasyczne Systemy Informacji Prawnej wyróżniają się na tle innych serwisów takimi cechami, jak: dążenie do maksymalnie szerokiej zawartości aktów prawnych, orzecznictwa, komentarzy, a także wielością metod wyszukiwania informacji. Wydaje się jednak, że w przyszłości podział na SIP i inne systemy będzie opierał się głównie na rodzaju wykładni prawa.

\section{METODY DYSTRYBUCJI}

Klasyczne Systemy Informacji Prawnej w Polsce dystrybuowane są najczęściej w sposób bezpośredni. Oznacza to, że producenci (wydawcy) posiadają własną sieć przedstawicieli handlowych (konsultantów), którzy na spotkaniach handlowych u potencjalnych klientów prezentują zawartość i funkcjonalność SIP, a następnie negocjują warunki sprzedaży. M. Waszczyk i S. Rodacki (2005) podkreślają, że sprzedaż bezpośrednia, w szerokim znaczeniu rozumiana jako wykonana przez jedną osobę w stosunku do drugiej prezentacja produktu połączona z propozycją zakupu, znana jest na świecie od tysiącleci. Trudno się z tym stwierdzeniem nie zgodzić, jednak w przypadku SIP mamy do czynienia ze znacznie węższym znaczeniem terminu ,sprzedaż bezpośrednia”. Otóż przedstawiciel jednej firmy (producenta) dokonuje tu najczęściej prezentacji produktu w siedzibie drugiej firmy (ang: B2B - Business to Business). Taki sposób dystrybucji produktów i usług na szerszą skalę w Polsce pojawił się po przełomie politycznym i gospodarczym w 1989 roku. Sprzedaż bezpośrednia jest dominującą metodą sprzedaży SIP od początku lat dziewięćdziesiątych (od początku istnienia SIP) do dnia dzisiejszego. Przez cały ten okres podejmowane były próby dywersyfikacji metod dystrybucji tych systemów. Równolegle do działań przedstawicieli handlowych wprowadzano takie metody, jak: sprzedaż wysyłkowa, sprzedaż poprzez telemarketing (wewnętrzny i zewnętrzny) czy możliwość zakupu poprzez internet. Niektóre z nich, np. telemarketing, znalazły zastosowanie przy odnowieniach (powtórna sprzedaż do tego samego kontrahenta na kolejny okres czasowy) lub przy sprzedaży tańszych systemów (np. systemy wertykalne nie będące klasycznymi SIP). Dominująca rola własnej sieci przedstawicieli handlowych wynika przede wszystkim ze złożonej funkcjonalności SIP i związanej z tym potrzeby bezpośredniej prezentacji u klienta w celu przedstawienia wartości merytorycznych i korzyści związanych z użytkowaniem systemu (ryc. 3). W tym celu przedstawiciel handlowy musi pełnić funkcję konsultanta, a więc oprócz typowych umiejętności handlowych powinien on dysponować odpowiednią wiedzą z zakresu prawa, ekonomii i biznesu.

Drugim istotnym czynnikiem determinującym proces sprzedaży jest cena produktu lub usługi, która w przypadku SIP jest stosunkowo wysoka. Im droższy produkt, tym trudniej jest go sprzedać bez osobistego kontaktu z potencjalnym odbiorcą. M. Makowska (2010) podkreśla, że dużym atutem sprzedaży bezpośredniej jest jej efektywność. Odpowiednio przeszkoleni dystrybutorzy mają indywidualny kontakt z klientem, możliwość bezpośredniej perswazji i negocjacji, co znacznie zwiększa szansę sprzedaży. 


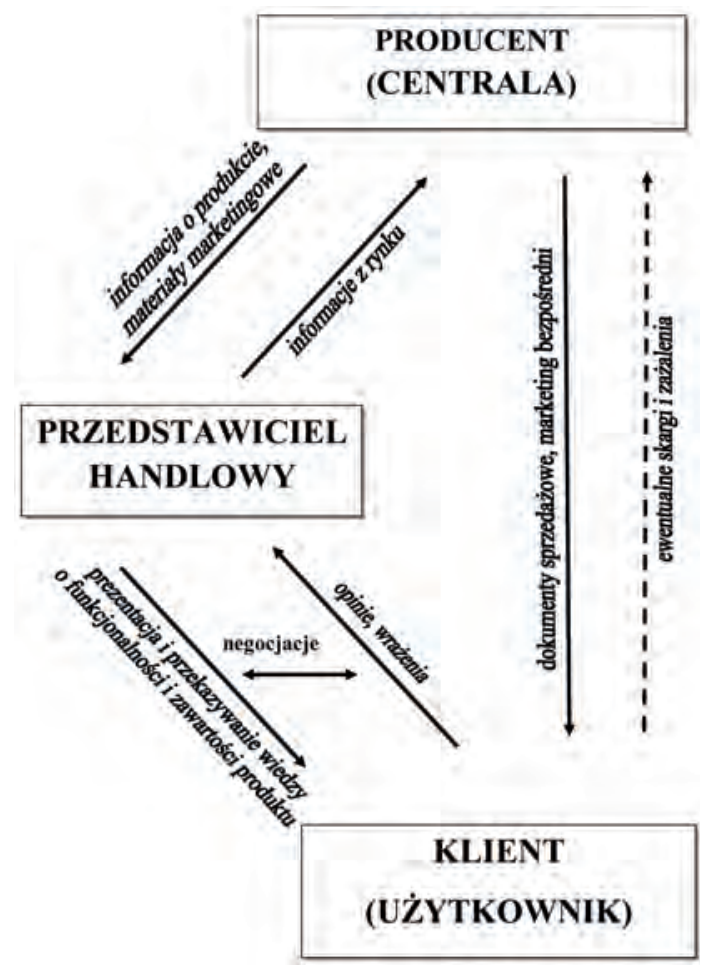

Ryc. 3. Proces dystrybucji Systemów Informacji Prawnej

Źródło: opracowanie własne

\section{Systemy Informacji Prawnej a gospodarka oparta NA WiEdZy}

Na podstawie przebiegu rozwoju SIP w Polsce można postawić tezę, że systemy te w znacznym stopniu przyczyniły się do upowszechnienia informacji prawnej i mają duży wkład w kształtowanie gospodarki opartej na wiedzy. Termin ,gospodarka oparta na wiedzy" (GOW) wg OECD (2005) opisuje trendy w gospodarkach rozwiniętych w kierunku wzrostu znaczenia wiedzy, informacji i wysokiego poziomu kwalifikacji oraz wzrostu zapotrzebowania na nie ze strony biznesu i sektora publicznego. J.T. Hryniewicz w swoim artykule (2010: 62) przyjął, że GOW polega na: zbliżeniu nauki do procesów tworzenia dóbr i usług, powstawaniu nowych wiedzochłonnych przemysłów, ekspansji sektora ICT (sektor technologii informacyjnych i komunikacyjnych) oraz stosowaniu jego wytworów we wszystkich innych sferach działalności. Systemy Informacji Prawnej, metody ich dystrybucji i zjawiska społeczno-ekonomiczne związane z ich rozwojem doskonale wkomponowują się w w termin GOW. 
Geneza powstania SIP związana była z rosnącym zapotrzebowaniem ze strony środowiska prawniczego na narzędzia informatyczne, które dostarczałyby aktualną, kompletną i usystematyzowaną informację prawną i prawniczą. Dzięki rozwojowi technologii informatycznych po okresie transformacji ustrojowej w Polsce stało się to możliwe. Według Naczelnej Rady Adwokackiej (2010) liczba osób profesjonalnie świadczących usługi prawne w Polsce w podziale na poszczególne profesje przedstawia się następująco (stan na 12 stycznia 2010): adwokaci - 10524, radcy prawni - 26050, notariusze - 2074, doradcy podatkowi -8714, komornicy - 788, rzecznicy patentowi - 938. Do tego należy doliczyć 428 jednostek prokuratury i 406 sądów powszechnych, administracyjnych i wojskowych - wg danych GUS (2012). To właśnie ta grupa profesjonalistów stanowiła pierwotny rynek dla rozwijających się prawniczych narzędzi informatycznych i w dalszym ciągu stanowi podstawową grupę użytkowników klasycznych SIP (w ostatnich latach liczba prawników z ukończoną aplikacją znacznie wzrosła). Liczba absolwentów prawa jest oczywiście znacznie wyższa niż liczba prawników po aplikacji. Zatrudnieni są oni m.in. jako specjaliści w administracji publicznej, w przedsiębiorstwach lub zajmują się zupełnie inną profesją. W artykule M. Domagalskiego (2010) ocenia się także (powołując się na dane Ministerstwa Sprawiedliwości), że połowa radców prawnych zatrudniona jest w firmach lub w administracji publicznej. Ogromna rzesza prawników pracujących na etacie miała i w dalszym ciągu ma duży wpływ na upowszechnianie klasycznych Systemów Informacji Prawnej w przedsiębiorstwach i administracji. Należy podkreślić, że Systemy Informacji Prawnej nie były tylko „skutkiem” (rozwoju technologii i zapotrzebowania rynku), ale stały się także czynnikiem upowszechniającym informację prawną, jak i samą technologię informatyczną. Ogromny udział w kształtowaniu GOW (szczególnie w początkowym okresie rozwoju SIP) miał także proces dystrybucji SIP oparty na modelu sprzedaży bezpośredniej (ryc. 3). Podstawowym problemem producentów Systemów Informacji Prawnej w latach dziewięćdziesiątych był stosunkowo duży opór ze strony potencjalnych klientów w zakresie obsługi komputera. Wśród prawników dominowały osoby starsze, które niechętnie wprowadzały innowacje w stylu swojej pracy. Wielu potencjalnych klientów z jednej strony odczuwało potrzebę posiadania nowoczesnego narzędzia, które ułatwiłoby im pracę, z drugiej strony występowało u nich zjawisko oporu przed nowością. Dlatego też przedstawiciele handlowi poszczególnych wydawców, oprócz funkcji typowo sprzedażowych, pełnili także funkcje „nauczycieli” podstawowych technik obsługi komputera. W dużym stopniu przyczynili się oni także do upowszechnienia SIP poza stricte środowiskiem prawniczym. Poszerzenie dystrybucji Systemów Informacji Prawnej poza pierwotny rynek związane było m.in. z nasileniem działań konkurencji i stało się nieuniknione w celu zapewnienia wzrostu sprzedaży producentom. Odbywanie spotkań handlowych z klientami, którzy nie byli specjalistami z zakresu prawa powodowało, że konsultanci musieli spełniać nowe funkcje, a mianowicie uświadamiać potencjalnych użytkowników, jakie korzyści niesie za sobą posiadanie aktualnej informacji prawnej.

W XXI wieku informacja prawna dotarła do szerokiego kręgu odbiorców i nie jest już tylko zarezerwowana dla specjalistów z zakresu prawa. Sprzedaż publikacji elektronicznych z zakresu prawa, biznesu i ekonomii (SIP, serwisy wertykalne, inne mniejsze narzędzia) wzrosła w latach 2001-2011 z 74 mln złotych do 398 mln złotych, czyli o 538\%. Ich udział 
w globalnej sprzedaży wszelkich publikacji (publikacje elektroniczne rozumiane są tu jako książki) wzrósł z 3,5\% w roku 2001 do 14,7\% w roku 2011 (tab. 1).

Tab. 1. Sprzedaż książek (w tym produktów elektronicznych) w mln PLN

\begin{tabular}{|c|c|c|c|c|c|}
\hline Rok & $\begin{array}{c}\text { Produkty elek- } \\
\text { troniczne (pra- } \\
\text { wo, biznes, } \\
\text { ekonomia) }\end{array}$ & $\begin{array}{c}\text { Książki naukowe } \\
\text { i fachowe (w tym } \\
\text { produkty elektro- } \\
\text { niczne) }\end{array}$ & $\begin{array}{c}\text { Książki ogółem } \\
\text { (w tym produkty } \\
\text { elektroniczne) }\end{array}$ & $\begin{array}{c}\text { Udział produk- } \\
\text { tów elektronicz- } \\
\text { nych z zakresu } \\
\text { prawa, biznesu } \\
\text { i ekonomii } \\
\text { w sprzedaży ksią- } \\
\text { żek naukowych } \\
\text { i fachowych }\end{array}$ & $\begin{array}{c}\text { Udział produktów } \\
\text { elektronicznych } \\
\text { z zakresu prawa, } \\
\text { biznesu i ekono- } \\
\text { mii w sprzedaży } \\
\text { książek ogółem }\end{array}$ \\
\hline 2001 & 74 & 490 & 2100 & $15,10 \%$ & $3,52 \%$ \\
\hline 2002 & 81 & 520 & 2080 & $15,58 \%$ & $3,89 \%$ \\
\hline 2003 & 91 & 525 & 2090 & $17,33 \%$ & $4,35 \%$ \\
\hline 2004 & 98 & 560 & 2210 & $17,50 \%$ & $4,43 \%$ \\
\hline 2005 & 112 & 615 & 2460 & $18,21 \%$ & $4,55 \%$ \\
\hline 2006 & 136 & 655 & 2380 & $20,76 \%$ & $5,71 \%$ \\
\hline 2007 & 181 & 715 & 2600 & $25,31 \%$ & $6,96 \%$ \\
\hline 2008 & 272 & 865 & 2910 & $31,45 \%$ & $9,35 \%$ \\
\hline 2009 & 324 & 940 & 2860 & $34,47 \%$ & $11,33 \%$ \\
\hline 2010 & 356 & 980 & 2940 & $36,33 \%$ & $12,11 \%$ \\
\hline 2011 & 398 & 985 & 2710 & $40,41 \%$ & $14,69 \%$ \\
\hline
\end{tabular}

Źródło: opracowano na podstawie Gołębiewski, Waszczyk 2012

Wśród publikacji fachowych i naukowych SIP i inne produkty elektroniczne z zakresu prawa, ekonomii i biznesu stanowią ponad 40\% rynku (w roku 2001 był to udział ok. 15\%) (tab. 1). Według Ł. Gołębiewskiego i P. Waszczyka (2012) rynek publikacji elektronicznych z zakresu prawa, biznesu i ekonomii to nie tylko najszybciej rozwijający się segment w obrębie rynku książki, ale też mający największe możliwości rozwoju.

Trudno jest oszacować liczbę użytkowników SIP i innych produktów elektronicznych podobnego typu. Związane to jest $\mathrm{z}$ tym, że publikacje te rozpowszechniane są nie tylko w postaci płatnych produktów na rynku komercyjnym, ale dostępne są także na uczelniach wyższych czy w bibliotekach. Z części z nich w okrojonej wersji można skorzystać w postaci darmowych serwisów internetowych.

Dla przykładu, stronę internetową gofin.pl (jeden z ważniejszych portali podatkowo-księgowych) odwiedziło już blisko milion unikalnych użytkowników. Coraz większą rolę odgrywają także wydawcy prasy fachowej, np. Gazeta Prawna (Infor Biznes) czy Rzeczpospolita (Presspublica). Dodają oni do swoich publikacji liczne załączniki, w tym oprogramowanie narzędziowe, oprogramowanie dla firm, dostępy do archiwum tekstów i komentarzy. Produkują także własne komentarze, korzystając z wiedzy nie tylko własnego zespołu, ale także zapraszanych w roli ekspertów autorytetów (Gołębiewski, Waszczyk 2012). 
Reasumując należy stwierdzić, że Systemy Informacji Prawnej odegrały i odgrywają znaczącą rolę w kształtowaniu gospodarki opartej na wiedzy w Polsce. Rola ta nie sprowadza się tylko do znaczącego udziału w PKB naszego kraju (udział ten jest znikomy), ale polega także na zbliżeniu wiedzy i informacji do procesów decyzyjnych zarówno w sektorze prywatnym, jak i publicznym. Systemy te w swojej klasycznej formie wyszły poza tradycyjny rynek prawniczy, dając impuls do tworzenia wielu innych narzędzi informatycznych skierowanych do szerokiego rynku odbiorców. Dzięki tym wszystkim narzędziom informacja prawna, ekonomiczna i biznesowa stała się informacją powszechnie dostępną.

\section{Podsumowanie}

Systemy Informacji Prawnej wykształciły się w Polsce po okresie transformacji przede wszystkim wskutek rozrostu, niestabilności i nadmiernej szczegółowości polskiego ustawodawstwa. W początkowym okresie rozwoju systemy te stały się ważnym narzędziem pracy głównie wśród prawników. W miarę upływu czasu zaczęły się rozprzestrzeniać poza tradycyjny rynek, docierając do przedsiębiorców i instytucji publicznych. Dały one także impuls do tworzenia wielu innych narzędzi informatycznych przekazujących informację prawną, ekonomiczną i biznesową do szerokiego kręgu odbiorców. Systemy Informacji Prawnej i metody ich dystrybucji odgrywały i odgrywają znaczącą rolę w kształtowaniu gospodarki opartej na wiedzy. Rola ta polega na zbliżeniu wiedzy i informacji do procesów decyzyjnych w sektorze prywatnym i publicznym.

\section{Literatura / References}

Domagalski, M. (2012, 22 listopada). Ilu w Polsce mamy prawników. Rzeczpospolita. Pozyskano z: http://prawo.rp.pl/artykul/430770.html.

Główny Urząd Statystyczny (2012). Mały Rocznik Statystyczny Polski. Warszawa: Zakład Wydawnictw Statystycznych.

Goetz, K.H., Zubek, R. (2005). Stanowienie prawa w Polsce. Reguly legislacyjne a jakość ustawodawstwa. Warszawa: Sprawne Państwo, Program Ernst \& Young. Pozyskano z: http://www.ey.com/ $\mathrm{PL} / \mathrm{pl} /$ Industries/Government---Public-Sector/Raport-Stanowienie-prawa-w-Polsce.

Gołębiewski, Ł., Waszczyk, P. (2012). Rynek książki w Polsce 2012. Wydawnictwa. Warszawa: Biblioteka Analiz.

Hryniewicz, J.T. (2010). Gospodarka oparta na wiedzy a globalne procesy geopolityczne. Prace Komisji Geografii Przemystu Polskiego Towarzystwa Geograficznego, 15, 61-68.

Janowski, J. (2011). Informatyka Prawnicza. Wyktady specjalizacyjne. Warszawa: Wydawnictwo C.H. Beck.

Kochanowski, J. (2012, 28 listopada). Jak powinno być tworzone prawo w Polsce? Wystapienie Rzecznika Praw Obywatelskich przed Senacka Komisja Ustawodawcza 14 września 2006 roku. Pozyskano z: http://www.rpo.gov.pl/index.php?md=1852\&s=1. 
Makowska, M. (2010). Sprzedaż bezpośrednia. Tajemnice i mity motywacji pracowników. Torun: EscapeMagazine.pl. Pozyskano z: http://www.escapemagazine.pl/119374-sprzedaz-bezposrednia.

Naczelna Rada Adwokacka (2012, 20 listopada). Ilu naprawdę jest prawników w Polsce: raport o dostępności pomocy prawnej - Naczelna Rada Adwokacka 12 stycznia 2010. Pozyskano z: http://www.adwokatura.katowice.pl/z-naszej-izby-szczegoly/items/raport-ilu-naprawde-jest-prawnikow-w-polsce.html.

OECD (2012, 21 listopada). Knowledge-Based Economy, Definition - 01.09.2005. Glossary of Statistical Terms. Pozyskano z: http://stats.oecd.orgglossary//detail.asp?ID=6864.

Waszczyk, M., Rodacki, S. (2005). Etos sprzedaży bezpośredniej. Problemy moralne a istniejące uregulowania kodeksowe. W: J. Kubka (red.), Z zagadnień filozofii zarządzania i etyki biznesu. Gdańsk: Wydawnictwo Politechniki Gdańskiej, 97-118.

Wierczyński, G., Wiewiórowski, W.R. (2012). Informatyka prawnicza. Nowoczesne technologie informacyjne w pracy prawników i administracji publicznej, wyd. 3. Warszawa: Wolters Kluwer.

Wiewiórowski, W.R. (2008). Zagrożenia związane z zarządzaniem informacją prawną i prawniczą w środowisku elektronicznym. W: H. Ganińska (red.), Informacja dla nauki a świat zasobów cyfrowych. Poznań: Biblioteka Główna Politechniki Poznańskiej, 82-95.

Zioło, Z. (2010). Uwarunkowania kształtowania się procesów transformacji przemysłu i usług. Prace Komisji Geografii Przemystu Polskiego Towarzystwa Geograficznego, 15, 45-60.

Bartlomiej Patkowski, mgr, Uniwersytet Pedagogiczny w Krakowie, Instytut Geografii, Zakład Przedsiębiorczości i Gospodarki Przestrzennej.

Doktorant Uniwersytetu Pedagogicznego w Krakowie, Instytut Geografii, ukończone studia magisterskie: Uniwersytet Jagielloński, Wydział Biologii i Nauk o Ziemi, Instytut Geografii, Akademia Ekonomiczna w Krakowie (obecnie Uniwersytet Ekonomiczny w Krakowie), Wydział Zarządzania. Zainteresowania badawcze autora to: geografia społeczno-ekonomiczna, przedsiębiorczość, zarządzanie.

Bartlomiej Patkowski, Ph.D. student, Pedagogical University of Cracow, Institute of Geography. Master's degree studies: Jagiellonian University, Faculty of Biology and Earth Sciences, Institute of Geography, Cracow Academy of Economics (Cracow University of Economics), Faculty of Management. His research interests are: socio-economic geography, entrepreneurship, management.

adres/address: Uniwersytet Pedagogiczny w Krakowie Instytut Geografii, Zakład Przedsiębiorczości i Gospodarki Przestrzennej ul. Podchorążych 2, 30-084 Kraków, Polska e-mail: bioklima@poczta.onet.pl 